\title{
4. Local and global aspects of coal in the ASEAN countries $^{1}$
}

\author{
Haakon Fossum Sagbakken, Aidai Isataeva, Indra Overland, \\ Aloysius Damar Pranadi, Beni Suryadi and Roman \\ Vakulchuk
}

\section{THE ENVIRONMENTAL, HEALTH AND ECONOMIC IMPACTS OF COAL}

The global energy system is currently undergoing a rapid transition, with profound consequences for the fossil fuel industries, perhaps most notably the one with the highest greenhouse gas emissions - coal. Having played a major role in recent decades, especially in rapidly growing emerging economies such as China and India, coal is being phased out across much of the world, as its environmental and health impacts have become prohibitively costly while its supposed economic advantages are rapidly disappearing as its relative affordability is undermined by the falling cost of renewable energy in many parts of the world (Finkelman and Tian, 2018; Gimon et al., 2019; Hendryx, Zullig and Luo, 2020; Kerimray et al., 2017; Rauner et al., 2020; Strasert, Teh and Cohan, 2019). Coal also has disproportionally large negative environmental and economic externalities in that its emissions degrade local agricultural, water and human resources (Bhuiyan et al., 2010; Hota and Behera, 2015). Coal's water requirements also put pressure on already strained water resources in places such as India, to the extent that water shortages render coal plants themselves unreliable (Wang et al., 2019, p. 3164). However, despite falling in status and despite their commitments under the Paris Agreement, coal is still favoured by many large developing countries and exposes them to significant economic and stranded asset risks as the cost of coal is being rapidly undercut by renewable energy technologies (Clark, Zucker and Urpelainen, 2020; Edenhofer et al., 2018, p. 2).

A significant body of research has examined the health, environmental and economic impact of coal use across the developing and developed world in recent years (Amster, 2021; Amster and Lew Levy, 2019; Henneman, Choirat and Zigler, 2019; Johnsen, LaRiviere and Wolff, 2019; Kravchenko and Lyerly, 2018; Munawer, 2018; Wang et al., 2019; Xiao et al., 2020). The negative health and environmental effects of coal are well known, with some concluding that the costs outweigh the short-term economic benefits (Rauner et al., 2020, p. 308). Others have pointed to the direct risks of coal plants becoming stranded assets due to rapidly changing energy markets as well as public pressure to adopt more stringent pollution

1 This is an open access work distributed under the Creative Commons Attribution -NonCommercial-NoDerivatives 4.0 Unported (https://creativecommons.org/licenses/by-nc-nd/4.0/). Users can redistribute the work for non-commercial purposes, as long as it is passed along unchanged and in whole, as detailed in the License. Edward Elgar Publishing Ltd must be clearly credited as the rights holder for publication of the original work. Any translation or adaptation of the original content requires the written authorization of Edward Elgar Publishing Ltd. 
standards (Caldecott, Dericks and Mitchell, 2015). Environmentally, local emissions and waste from coal plants poison agricultural fields and local water supplies, a problem that is magnified with subcritical plants often built in developing countries due to their lower cost. This can cause not only a loss in livelihoods, but also migration or even forced resettlement. Emissions from coal plants have proven deleterious effects on human health (Buchanan, Burt and Orris, 2014, p. 266; Burt, Orris and Buchanan, 2013, p. 2; Chen et al., 2014, p. 736; Finkelman and Tian, 2018, p. 579; Munawer, 2018, p. 87; Silva and da Boit, 2011, p. 187). In addition, coal consumption entails coal mining, which is a hazardous occupation with not only long-term health impacts on workers but also putting them at high risk of accidents (Hendryx, 2015 , p. 823). As coal use grows, so necessarily does mining and the frequency of accidents, as has been observed in the case of China for decades (Dhillon, 2010, p. 68). Mining accidents tend to be more frequent in developing countries due to lower security requirements and more labour-intensive methods of extraction.

The international community has developed few tools for pressuring and assisting countries to phase out coal (Ayling and Gunningham, 2017; Green, 2018; Kalkuhl et al., 2019; Richardson, 2017; Trinks et al., 2018). Recent studies point out that intergovernmental initiatives aimed at attaching a stigma to coal suffer from a lack of member states among major coal-consuming countries (Blondeel, Van de Graaf and Haesebrouck, 2020, p. 3). They are mainly developing countries with newer coal plants with longer remaining lifespans (Jewell et al., 2019). No national government has yet put restrictions on coal power as part of its foreign policy towards other states. Nor are there any mechanisms for punishing countries that fail to abide by their commitments under the Paris Agreement because they build new coal power plants, such as by massively expanding coal (Karlsson-Vinkhuyzen et al., 2018; Kemp, 2018; United Nations Framework Convention on Climate Change [UNFCCC], 2015). Thus, for the time being, effective political and social opposition to coal power plants is more likely to play out in national and local arenas than at the global level, as most national governments must in some way take public sentiment into account when making energy policy (Overland, 2018). Local resistance to coal exists in various forms in many countries, from Australia (Higginbotham et al., 2010) to Bangladesh, to Turkey (Arsel, Akbulut and Adaman, 2015). Such dynamics have become particularly apparent in countries seeing rapid expansion of coal power, several of which are members of the Association of Southeast Asian Nations (ASEAN).

Against this backdrop, the ASEAN member states have been enthusiastically embracing coal in recent years. As much of the world is pivoting away from fossil fuels, many Southeast Asian countries have been rapidly expanding their use of coal to meet the region's rising energy consumption, chiefly the projected rise in demand for electricity (Clark et al., 2020; Overland et al., 2021). In 2019, coal demand was projected to grow 5 per cent annually in Southeast Asia through 2023, the highest growth rate in the world. Along with Chinese and Indian demand, this has contributed to maintaining a high level of coal consumption globally (Figures 4.1 and 4.2) (International Energy Agency [IEA], 2019a).

As regional gas and oil reserves rapidly deplete, the ASEAN countries have made a sharp turn towards coal (ASEAN Centre for Energy [ACE], 2017, p. 2; Cornot-Gandolphe, 2016, p. 3; Shi, 2016, p. 678). Figure 4.1 shows that in 2019 the IEA projected that ASEAN demand 


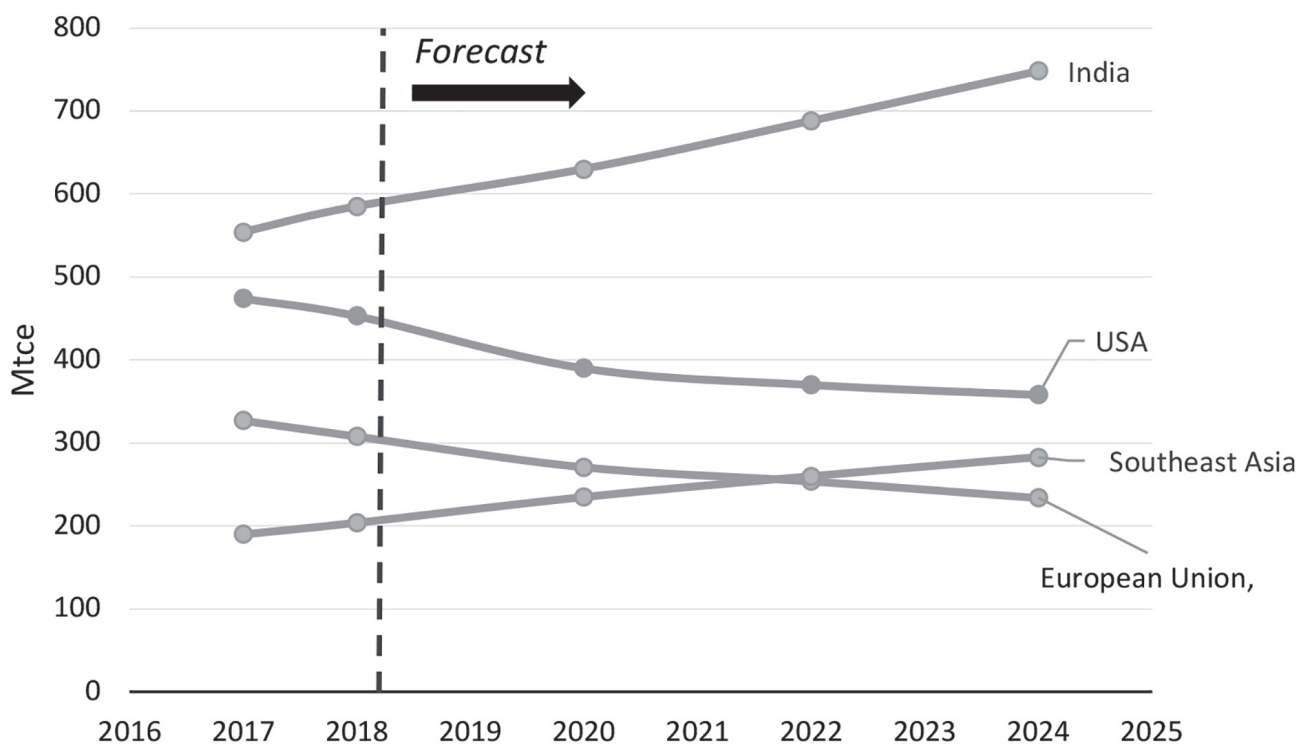

Note: $\quad$ Mtce $=$ million tonnes of carbon equivalent. China is omitted as its dominant role in global coal consumption would distort the graph.

Source: IEA (2019b).

Figure 4.1 Coal consumption by selected regions/countries, 2017-24

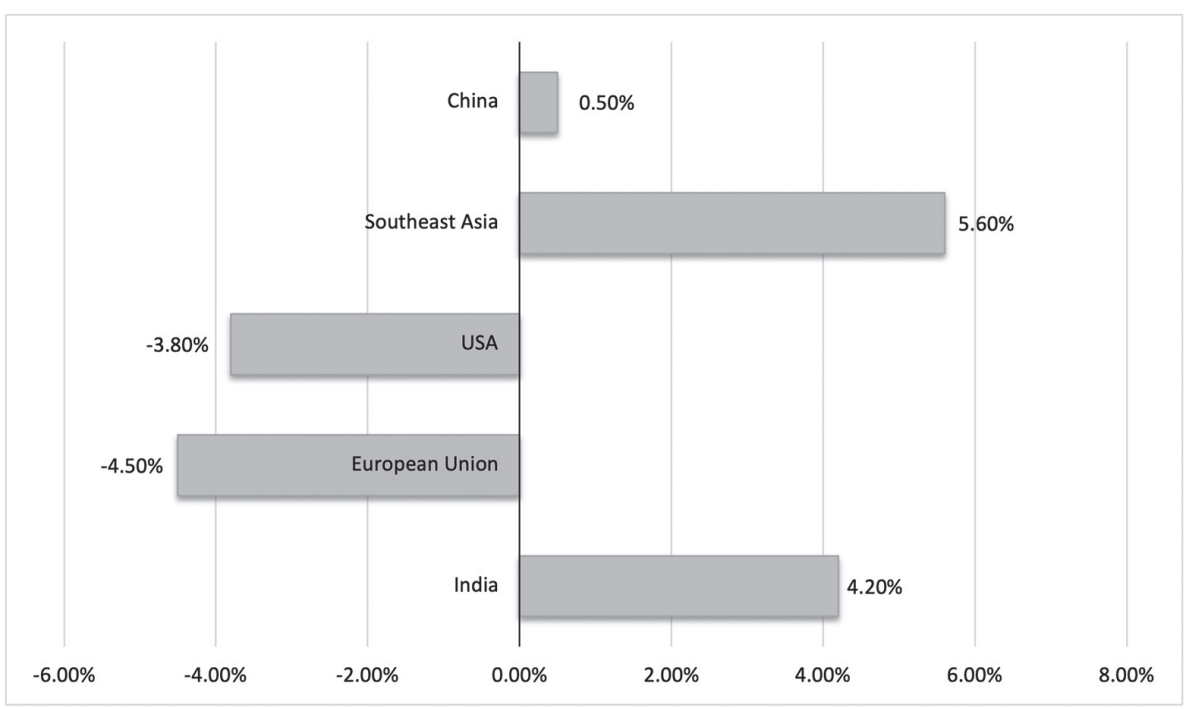

Source: IEA (2019b).

Figure 4.2 Projected compound average annual growth rate (CAAGR) of coal consumption 2017-24 
for coal would overtake that of the EU by 2022 (IEA, 2019b). The same year, IEA estimated that, while the rest of the world, on average, is phasing out or limiting new coal plants, ASEAN coal demand will grow by 3 per cent every year until 2040, building on the rapid pace of deployment since the turn of the millennium.

In 2018, ASEAN was the only part of the world in which coal's share in the electricity generation mix increased (IEA, 2019b, p. 20). As shown in Figure 4.2, ASEAN's coal consumption has been predicted to increase more rapidly than that of any other major region and significantly faster than China from 2018 to 2024 (ibid.). Indonesia and Vietnam are the main drivers of this trend. From 2000 to 2018, the share of coal in the ASEAN electricity generation mix doubled, and currently accounts for 40 per cent, a level that the IEA predicts will be stable until at least 2040 (IEA, 2019c). The net addition of 90 gigawatts (GW) of coal power in ASEAN from 2019 to 2040 contrasts starkly with global energy transition trends (IEA, 2019c).

Within the shorter period from 2008 to 2017, a staggering 39990 megawatts (MW) of coal power capacity were added in the ASEAN countries (ACE, 2019). Paradoxically, and as shown in Figure 4.3, ASEAN's installed coal power capacity grew rapidly at the same time as the threat of climate change became an increasingly prominent public policy concern and a threat to sustainable development in the years preceding the Paris Agreement. Indonesia and Vietnam were the two main contributors (Figure 4.3). Indonesia alone raised the installed capacity of its coal-fired power plants by 17920 MW from 2008 to 2017, with Vietnam adding 12513 MW during the same period. In the decade from 2008 to 2018, the compound annual growth rate (CAGR) of coal consumption in ASEAN was 7.8 per cent, dwarfing any other major consuming region in the world (IEA, 2019b, p. 15).

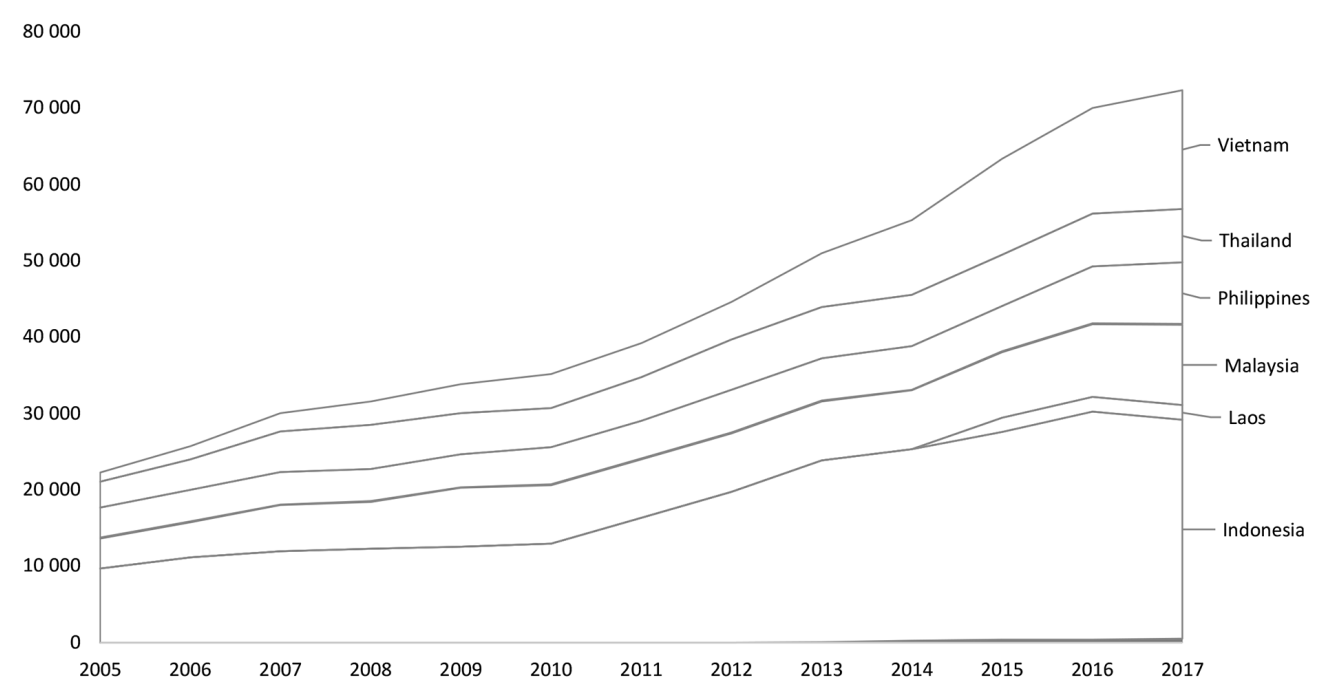

Note: $\quad$ Coal does not play a significant role in Singapore and Brunei Darussalam, hence their exclusion from Figure 4.3.

Source: $\quad$ ACE database 2019.

Figure 4.3 Annual installed capacity of coal power plants in the ASEAN member states, 2005-17 
The IEA predicted in 2019 that coal would replace gas as the main energy source for power generation in Southeast Asia by 2030 (IEA, 2019c, p. 62). As shown in Figure 4.4, demand is driven chiefly by Indonesia, Vietnam and the Philippines, but with Myanmar, Malaysia and Laos also including coal as a key component of their future energy systems (see also International Renewable Energy Agency [IRENA], 2018, p. 34). Myanmar's Energy Master Plan envisions coal providing 30 per cent of electricity production by 2030 (IEA, 2020a). However, with almost 50 per cent of the population still lacking access to electricity in 2019 (IEA, 2019c), Myanmar also has a unique opportunity to avoid such a coal-centric scenario when undertaking grid planning (Sternagel, 2018). It could utilize its high renewable energy potential instead (Vakulchuk et al., 2017). Even Cambodia, which lacks significant domestic energy resources, signed a power purchasing agreement (PPA) in 2019 for large coal-generated electricity imports from Laos for the coming decades (Vanda, 2019), despite the latter's established image as a mainly hydropower-exporting country and its aspirations to become the hydropower 'battery of Southeast Asia' (Watcharejyothin and Shrestha, 2009; Yu, He and Phousavanh, 2019). Coal is a non-existent part of the energy system of Brunei and is negligible in the electricity production in Singapore (less than 1 per cent), although these countries will also remain dependent on fossil fuels for the foreseeable future (IEA, 2020b, 2020c; Quek et al., 2018). It is also noteworthy that almost all the current and planned new coal plants in the ASEAN countries, with the exception of Malaysia, are the least efficient subcritical type of power plants (Climate Analytics, 2019, p. 42).

ASEAN's coal expansion is a potential lifeline for both the regional and global coal industries. Arguably, regional coal utilization is particularly in the interest of Indonesia, which holds some of the world's largest reserves and stands to enhance its already dominant position in the global export market. Indonesia was the world's largest exporter of coal in 2018, having jostled with Australia for the top spot in the preceding years, and accounted for double the volume of that of the third-largest exporter, Russia, in that year (IEA, 2019a). This may be of particular importance to Indonesia since its status as a net oil exporter has waned with the depletion of its reserves and lack of new major discoveries.

Demand for coal is projected to exceed domestic reserves in all ASEAN countries except Indonesia. Thus, Southeast Asian demand would also help maintain the global coal industry (World Coal Association [WCA], 2019). Australian coal exporters and Japanese and Korean coal plant construction firms face significantly less stringent environmental standards in ASEAN than in their home markets (Jong, 2019a; Zhao and Alexandroff, 2019, p. 518). The Southeast Asian coal sector is also attractive to Chinese coal plant builders, as they are likely to face more stringent emissions standards and domestic demand is projected to taper off in the coming years (Yuan et al., 2018, p. 443). Hence, Chinese firms already have a major presence in the Indonesian and Vietnamese coal sectors (Shearer, Brown and Buckley, 2019). Thai firms have also become active players in the Greater Mekong Region, seeking to construct power plants in Myanmar for electricity exports back to Thailand (Sternagel, 2018). Due to the unpopularity of coal plants in Thailand, Thai investors have already constructed a coal power plant in Laos which will mainly supply the Thai electricity grid (Deboonme, 2012). Such circuitous transnational plans and preference for frontier markets such as Laos and Myanmar despite the high transmission costs back to Thailand underline the social costs and risks that coal power already faces in Thailand and the multifaceted pressures on the industry in Southeast Asia. 

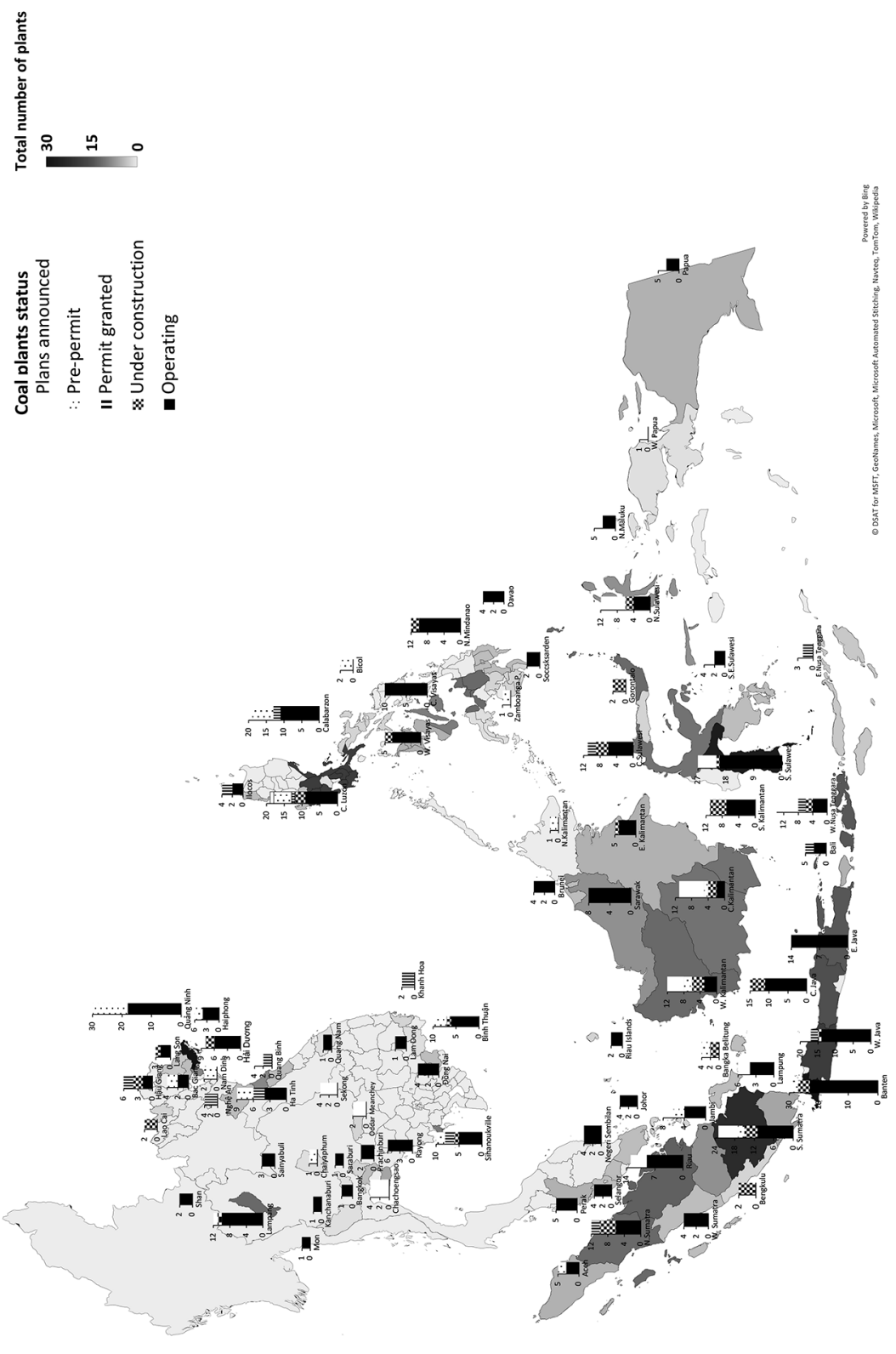

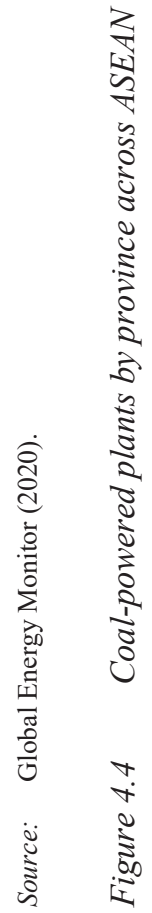




\section{THE IMPACT AND RISKS OF BETTING ON COAL IN SOUTHEAST ASIA}

Coal-centric policy planning exposes the ASEAN countries to significant economic risks. The current hazards and future risks of coal as an energy source have been examined at both regional and national levels in Southeast Asia (Shi, 2016). The Carbon Tracker Initiative has noted that the combination of steadily lower prices for renewables and higher standards for particle emissions driven by public discontent with coal plant pollution will likely make coal less economic than solar power in Indonesia, the Philippines and Vietnam within less than a decade, despite the fact that these countries are planning the greatest expansions in coal capacity in Southeast Asia (Carbon Tracker, 2018a, 2018b, 2018c). By 2025, rapidly rising domestic demand for electricity in Indonesia might curtail the ability to maintain current export levels as domestic consumption eats up the supply (Cornot-Gandolphe, 2017, p. 2). Another element of uncertainty is foreign investor scepticism about unpredictable and costly royalties (ibid., p. 23).

As a consequence of these developments and prospects, other ASEAN countries that are expanding their dependency on coal, and thus increasing their reliance on Indonesian policymaking, face greater energy insecurity. Large importing countries, such as China and India, although not projected to expand coal at the same pace as the ASEAN countries, will by virtue of their size remain major competitors for Australian coal. Southeast Asia has already seen competitive financing for coal plant projects dry up and be hampered by ambitious coal plans in ASEAN in the past two years (IEA, 2019c). In sum, the reliability and affordability of coal appear to hold largely illusory benefits for most ASEAN countries in the long run.

Even as the global climate crisis, international pressure to decarbonize and plummeting costs of renewables make coal increasingly unpalatable and uneconomic, ASEAN leaders continue to emphasize promotional campaigns for 'clean coal' and the 'benefits of coal' to their general publics in joint communiqués from regional energy summits (see, for example, ASEAN, 2019). However, despite the longstanding rhetoric and lack of specifics about the supposed mitigating factors of 'clean coal technologies', as of 2020, ASEAN had only a single ultra-supercritical coal power plant, Malaysia's 100 MW Manjung 4. Thailand is planning to refit an old coal plant with supercritical technology to provide $660 \mathrm{MW}$ capacity, yet this plant is, and will continue to be, powered by lignite, the least efficient and most environmentally harmful form of coal. However, the maintenance of such plants is framed as environmentally sound, as the particle emissions having the most hazardous effects on local public health will be curtailed (Paiwan, 2019). Even in planned capacity additions, subcritical and supercritical plants will account for the bulk of expansion up to 2040 (IEA, 2019c, p. 69). Coal mining, which within ASEAN is concentrated in Indonesia, also poses significant risk of accidents, as many mines lack proper security infrastructure and protective measures for workers (Anggoro and Simorangkir, 2019).

The ASEAN member states have received due criticism for their coal expansion as it undermines their international climate commitments (Clark et al., 2020; Overland et al., 2017; Prakash, 2018). International organizations note that the region has significant untapped renewable energy potential that could be exploited instead of coal (IEA, 2019c; IRENA, 2018). A Massachusetts Institute of Technology study from 2018 estimated that ASEAN countries must collectively cut emissions by 11 per cent by 2030, compared with the current trajectory, to meet their nationally determined contributions (NDCs) under the Paris Agreement, which 
are in many ASEAN states defined as being against business-as-usual (BAU) scenarios (Fulton et al., 2018). While an 11 per cent cut would be significant, the projected role of coal as providing over half of electricity demand in the Philippines and Vietnam by 2030 (ACE, 2017, p. 15; Philippine Power Statistic, 2018) in this scenario underlines the future high growth of emissions from the region even if the NDCs are met, at a time when much of the world is aiming to reduce emissions in absolute terms. Berlin-based Climate Analytics, in cooperation with the United Nations Environmental Programme (UNEP), estimated in 2019 that coal's share in electricity generation in ASEAN would have to fall below 8 per cent by 2030 to meet the Paris Agreement's targets of limiting the temperature rise to $2^{\circ} \mathrm{C}$. The IEA projected that the share will be about 40 per cent (IEA, 2019c, p. 65). Coal's expansion is a deliberate result of governments' budget priorities, as public spending accounts for the bulk of investments in new plants from 2014 to 2018 (ibid., p. 16). With current policies (as of 2020), ASEAN will emit 2.4 gigatons of $\mathrm{CO}_{2}$ in 2040, overshooting any target in the Paris Agreement by a wide margin, with coal being responsible for nearly 50 per cent of these emissions (ibid., p. 101). However, the climate change impact is only part of the picture, as coal plants and mines have, and will continue to have, an immediate impact on the local population, to which we turn in the next sections.

\subsection{Health Impacts of Coal in ASEAN}

Coal-fired power plants also pose a more immediate threat to health and local economies across the region. With much of Southeast Asia having little wind and limited space, the abundance of coal-fired power plants in close proximity to population centres has had profound public health implications. Respiratory diseases are a rapidly growing health hazard in Southeast Asia due to forest fires, urban congestion and industrial emissions - with coal plants playing an increasingly prominent role (Koplitz et al., 2016; Ming et al., 2018; Tacconi, 2016; Taghizadeh-Hesary and Taghizadeh-Hesary, 2020). A 2017 study estimated annual excess deaths from coal-induced surface air pollution at 19880 in the region, projected to rise to 69660 by 2030 at the current pace of power plant expansion (Koplitz et al., 2016, p. 1467). In one commune in Vietnam, Ky Loi, cancer rates resulting from coal emissions have soared, to the extent that in 2019 its 11000 residents were scheduled to be resettled, paradoxically to make more space for additional coal plants (Le, 2019).

\subsection{Water, Agricultural and Economic Impacts}

Coal plants represent a multifaceted threat to the water resources of Southeast Asia, with significant health and agricultural implications. Coal plants require substantial water volumes for cooling (Huang, Ma and Chen, 2017; Qadrdan et al., 2019; Zhang et al., 2017). A recent study noted how many newly built Indian coal plants had to temporarily shut down due to water shortages in recent years, and that the current Southeast Asian plans for coal expansion would put further stress on the region's already depleted water resources (Wang et al., 2019, p. 3164). Coal plant waste also poses a threat to riverine livelihoods in the region, not only in terms of contaminating drinking water but also undermining fisheries (Runivarajom, 2018). Coal plant fly ash also poses a threat to water quality, impacting drinking water sources and irrigation. More directly, ash from coal plants has already poisoned agricultural fields, triggering local 
protests in Batang in Central Java (Darmawan, 2019), Kalimantan (Funfgeld, 2018, p. 223) and multiple locations in Vietnam (Le, 2019).

Although difficult to measure quantitively before it is too late, coal plants may also pose a threat to the tourism sector in Southeast Asia. For years, Thailand had been planning to enhance electricity supplies to its southern provinces by means of new coal-fired power plants, partly to meet demand as the tourism sector expanded. Yet, according to the provincial tourism board, the choice of coal and its emissions may undermine the attractiveness of one of the world's tourism hotspots (The Nation Thailand, 2018a). Vietnam's famous Ha Long Bay is already facing ecological problems, with coal plants onshore in Quang Ninh Province and coal shipping through the bay being amongst the major culprits (Tran, Pham Le and Le Thi, 2019). Coal plants similarly risk undermining the tourism sector on Bali, with projects proposed for construction near popular beaches and national parks (Greenpeace, 2018).

Coal mining has also had negative effects on local communities and agriculture in other parts of Indonesia (Fatah, 2008). In East Kalimantan, land grabs and pollution have forced local farmers to resettle as mining firms exploit the large reserves (Tondo and Siburian, 2019). This trend is likely to intensify as this area holds a significant portion of Indonesia's coal reserves, and the Indonesian government plans to move the national capital there from Jakarta in the 2020s (Shani, 2019).

\section{EVOLVING RESISTANCE TO COAL POWER IN ASEAN}

Faced with such implications and considering the rapid expansion of coal to date, it is not surprising that opposition both to coal-fired power plants and coal mining has been growing across the ASEAN region. Opposition ranges from local groups fearing for their health and livelihoods to emerging nationwide campaigns emphasizing climate implications. The form of resistance and the level of coordination amongst environmental groups and international civil society in each country is shaped by the national socio-political conditions. This section maps the heterogeneous opposition to coal-fired power plants in ASEAN states from 2010 to 2020 , including the framing of grievances and the domestic socio-political dynamics that shape both the nature and effectiveness of this resistance. As protests are ongoing and have, to varying extents, already changed policy trajectories, we have scoured newspapers and other news sources covering environmental, coal and mining issues in Southeast Asia in an attempt to answer the following questions:

- Is opposition localized to specific plants or mines (and thus fragmented) or national in nature?

- What is the format of the opposition (on-site protests, marches, online campaigns, etc.)?

- Are grievances local, national or global in essence?

- Which political constituencies and actors comprise the opposition to coal projects?

- Have resistance efforts been successful at the local, provincial or national level?

- Which social, political or economic conditions are prerequisites for successful resistance? 


\subsection{Resistance to Coal Mining in Indonesia: A Fragmented Phenomenon}

Southeast Asian opposition to coal mining is mainly concentrated in the countries with significant coal reserves. ASEAN holds about 4 per cent of global proven recoverable reserves (IRENA, 2018, p. 32); however, although demand is growing across much of the region, the distribution of coal reserves is highly uneven. Indonesia is amongst the world's top coal exporters and holds over 80 per cent of ASEAN's coal reserves, both hard coal and lignite (ibid., p. 32). Coal mines have had a significant negative impact on local communities across Indonesia for many decades, as insufficient legislation and enforcement have led to inadequate safety standards, lax waste containment and lack of protection or compensation for local communities (Ballard, 2001, p. 3). Due to the large size and de facto decentralized governance of much of Indonesia outside Java, some mining projects were approved by local authorities without complying fully with the national legal framework. Even regionally approved legislation to enhance mine safety has often been ineffective (Toumbourou et al., 2020).

However, Indonesia also has a rich history of environmental activism, which was treated more leniently than other public expressions of discontent under the Suharto regime (1967-98) (Brown and Spiegel, 2017, p. 108). This, coupled with the massive expansion in coal mining and export in recent years, has prodded local Indonesian activists and the affected communities to partner with international non-governmental organizations (NGOs) to protest against mines in ecologically rich yet vulnerable areas such as Kalimantan (ibid., p. 106). Local opposition to new coal mines in West Papua is also growing, with local activists fearing that their environmental impact could further escalate the longstanding armed conflict in the restive province (Firdaus, 2018). In early 2020, local activists won a legal victory when the Indonesian supreme court ordered a mining permit in Central Kalimantan to be revoked on the grounds that it had not gained the approval of local communities, whose opposition centred on the threats to their livelihoods posed by the mine (Jong, 2020). The dispersed nature of Indonesian anti-mining activism to some extent reflects the country's vast and diverse geography, rendering coordination amongst impacted local communities difficult.

\subsection{Anti-mining Activism in ASEAN}

In Vietnam, which has the ASEAN's second-largest reserves of hard coal after Indonesia, coal mining is a hazardous activity. Yet, strong government control of the industrial sector appears to have prevented systemic protests against coal mines, as shown in Table 4.1. Protests have erupted over specific mining projects in the past, although chiefly due to foreign ownership concerns and growing anti-Chinese sentiment (Lam, 2018). In contrast, Malaysia's plans to expand coal mining in Sabah encountered stiff opposition in 2018 (Table 4.1). Local NGOs, coordinating with international environmentalist groups and regional political parties in Sarawak and Sabah, argued that states in Malaysia should have greater influence over resource management (Joibi, 2018). Local protests emphasizing regional rights have also taken place in Myanmar, notably in Shan State (Table 4.1), where villagers have held peaceful protests against new coal mines, focusing on local environmental degradation, although, in Myanmar's case, it also has an ethnic minority rights dimension (Mon, 2019; Sternagel, 2018). 
Table 4.1 Opposition to coal mining in Southeast Asia 2010-20

\begin{tabular}{lllll}
\hline & Presence of Protests & Areas of Grievances & Local or National Focus & Policy Effects \\
\hline Vietnam & None found & $\mathrm{n} / \mathrm{a}$ & $\mathrm{n} / \mathrm{a}$ & $\mathrm{n} / \mathrm{a}$ \\
Malaysia & At least one (Sabah) & Agriculture, tourism, ecological & Supported by national political & None found \\
& & conservation & parties & \\
Indonesia & Widespread & $\begin{array}{l}\text { Degraded fisheries, agriculture, } \\
\text { livelihoods, tourism, public health }\end{array}$ & Protest march in Jakarta & $\begin{array}{l}\text { Suspended one } \\
\text { mining licence }\end{array}$ \\
& & Agriculture, livelihoods & Local village-centric activism & None found \\
\hline
\end{tabular}

\subsection{Resistance to Coal-fired Power Plants in ASEAN}

Protests against coal-fired power plants are also widespread in Indonesia (Table 4.1), and they exhibit increasing signs of national and even international coordination. Importantly, the Indonesian government has curtailed the authority of local government bodies to block new licences for coal plants, preventing local residents from exerting political influence on their local administrations to halt new projects (Jong, 2019b). This prevents the widespread circumvention of national laws at the provincial level, but it also robs local activists of the power to exert successful political pressure on their local authorities to halt new coal projects, since it centralizes decision-making power in Jakarta. Nevertheless, protests in Indonesia have been multifaceted and widespread, although not always massive, strongly emphasizing local environmental and health impacts, even by protestors travelling to Jakarta to make their case (Jong, 2019a). In some more remote provinces, police have brutally cracked down on protestors (Karensa, 2016). In early 2017, over 2000 people from affected communities gathered in Jakarta and marched against coal, highlighting its negative impact on local livelihoods and health across the archipelago (Jatam, 2017). However, the links to climate change were not clearly articulated, and 2000 protestors is not a very large crowd on an Indonesian scale.

Opposition to specific plants in Indonesia, Myanmar, the Philippines, Thailand and Vietnam have all been spearheaded by locals concerned about the effects of coal emissions on the immediate environment. Farmers in Batang in Indonesia expressed concerns about emissions from a new nearby plant in 2019 poisoning their agricultural fields (Darmawan, 2019), as did villagers in Karen State in Myanmar in the same year (Thant, 2019). In the latter case, resistance was also triggered by the fact that the plant was intended to sell most of its electricity to the Thai market, with limited benefits or improved supply for the local community. In Myanmar, local communities have formed organizations in recent years to protest specific projects (Sternagel, 2018), which unfortunately has only caused coal plant construction firms to pursue the project in another area. Villagers' concerns about local waste effects led to suspension of a plant in Karen State in 2018 (Environmental Justice Atlas, 2018). In previous similar projects, local protestations proved unsuccessful (Win and Win, 2016). In Binh Thuan Province, local health-focused protestors rallied in 2015 in a rare display of physical protest in Vietnam and forced the Vietnamese government to impose superficial restrictions on a new plant's emissions (AP, 2015). However, a similar situation developed in the following years about another planned coal plant in the province, although the small-scale protests by that point were also emphasizing climate change as well as public health (Banktrack, 2020). However, both the existing plant and planned project are still set to continue. Laos, with only a single large coal plant as of 2020, has yet to see major protests, which is likely explained 
by the small size of the town close to the plant as well as the Laotian one-party system that restricts almost all organized civic or environmental activism.

Interestingly, despite protests in 2010 and 2011 against new plants, Malaysia has not seen major efforts by activists to stop new coal plants in recent years even though coal is an important source of power and will continue to remain so in the coming decades. This is not to say Malaysia does not have its fair share of climate or environmental activism, but this appears thus far to be focused on issues other than coal plants, such as deforestation and the country's large palm oil industry (Ocharoenchai, 2019).

Environmental activism and anti-coal protests have also been growing an online presence. Vietnam, in which the ruling socialist party controls most traditional media outlets and prohibits mass public protests, has seen a stronger presence of online campaigns against coal power, with national pop culture celebrities participating (Mekong Eye, 2016). However, the nature of the Vietnamese political system has limited any mass protests, local or provincial, despite massive environmental damage caused by coal emissions and waste in recent years (Tran et al., 2019). Nevertheless, there have been recent cases of NGOs successfully lobbying the government to limit future expansions, despite environmental activism carrying great risks in Vietnam (Bangkok Post, 2020). There have also been occasional climate protests in Vietnam, yet these have been rare and not focused on coal, but rather more broadly on air pollution (Palatino, 2019).

The Philippines has arguably seen the most cohesive environmentalist pushback against coal in the ASEAN region. A key facet of Philippine activism is the emergence of national campaigns that have put pressure on both the central government and local administrations in recent years. Piglas Batangas! Piglas Pilipinas!, a national campaign launched by civil society groups in 2016, has organized demonstrations against various projects across the country, including large protest marches. Importantly, this initiative has ties to broader global climate activist networks. As the Philippine government has rapidly expanded the import and use of coal, local and nationally coordinated opposition has been growing, emphasizing the health, economic and climate change implications. Local churches have played a key role in organizing local communities to stage protests and launch petitions (Bugnot, 2018). The most noteworthy example of a multifaceted opposition effort to coal plants in the region, in terms of complex socio-political coordination as well as the multifaceted nature of grievances, has taken place in two provinces in the Philippines: Negros Oriental and Negros Occidental. These provinces make up the nation's fourth-largest island, Negros in the Visayas, and effectively forced a phase-out of coal plants and proposed projects in 2018 and 2019, with the governors involved citing both local health concerns and the threat of climate change (Partlow, 2019; San Jose, 2019). The persistence of local youth protest initiatives, coupled with national exposure through national environmental networks, has likely played a significant role in pressing through this policy change. Despite this, coal remains a key priority for the Duterte administration, which touts its properties as 'clean energy' necessary to ensure energy security (Thomas, 2019). Ironically, almost all coal consumed in the country is imported, rendering its contribution to energy security questionable (Philippine Power Statistic, 2018).

Thailand has also seen an increasingly nationally coordinated anti-coal network of activists emerge in recent years, emphasizing both local health and economic concerns as well as climate change. In September 2019, as part of the Global Climate Strike action, approximately 150 petitioners carried out a 'die-in' demonstration representing death from climate change 
Table 4.2 Opposition to coal-fired power plants in Southeast Asia 2010-20

\begin{tabular}{|c|c|c|c|c|c|}
\hline & $\begin{array}{l}\text { Local and/or } \\
\text { National Focus }\end{array}$ & Grievances & Format of Opposition & $\begin{array}{l}\text { Centre-Periphery Government } \\
\text { Dynamic }\end{array}$ & Policy Effect/Changes \\
\hline Vietnam & National & Health & Online & None - highly stratified & None \\
\hline Indonesia & Local & $\begin{array}{l}\text { Health } \\
\text { Livelihoods }\end{array}$ & $\begin{array}{l}\text { Local protests } \\
\text { Protest march in } \\
\text { Jakarta }\end{array}$ & $\begin{array}{l}\text { Local government } \\
\text { marginalized }\end{array}$ & None \\
\hline Philippines & $\begin{array}{l}\text { Local and } \\
\text { national }\end{array}$ & $\begin{array}{l}\text { Climate } \\
\text { Health } \\
\text { Livelihoods }\end{array}$ & $\begin{array}{l}\text { Local protests } \\
\text { National } \\
\text { demonstrations }\end{array}$ & $\begin{array}{l}\text { Local governments in two } \\
\text { cases instrumental in anti- } \\
\text { coal policy adoption }\end{array}$ & $\begin{array}{l}\text { Successful local policy } \\
\text { moratoriums }\end{array}$ \\
\hline Thailand & Local & $\begin{array}{l}\text { Health } \\
\text { Tourism } \\
\text { Climate change } \\
\text { Livelihoods }\end{array}$ & $\begin{array}{l}\text { Local protests } \\
\text { National protests }\end{array}$ & $\begin{array}{l}\text { Local tourism associations } \\
\text { side with demonstrators }\end{array}$ & $\begin{array}{l}\text { Successful suspension } \\
\text { of two new projects }\end{array}$ \\
\hline Myanmar & Local & $\begin{array}{l}\text { Health } \\
\text { Livelihoods }\end{array}$ & Local protests & $\begin{array}{l}\text { Local governments at odds } \\
\text { with protestors }\end{array}$ & $\begin{array}{l}\text { Successful prevention } \\
\text { of at least one plant }\end{array}$ \\
\hline
\end{tabular}

Note: Cambodia, Laos and Malaysia were omitted because no data were found.

outside the Thai Ministry of Natural Resources and Environment, demanding coal to be phased out in the country (Palatino, 2019).

In late 2018, after years of protests and public hearings, the Electricity Generating Authority of Thailand (EGAT) indefinitely postponed the construction of coal power plants in Songkhla and Krabi in the southern part of the country in favour of increased reliance on natural gas (The Nation Thailand, 2018a). The protests included publicized hunger strikes in Bangkok (Bangkok Post, 2018), and were driven by a number of relevant arguments. These ranged from local residents citing public health concerns, threats to fisheries and the area's tourism sector, to local NGOs framing the issue in terms of climate change (The Nation Thailand, 2018b). In Krabi, the local tourism board was also highly sceptical of the proposed plants, as the region constitutes the heartland of the Thai tourist industry.

Resistance to coal power in Southeast Asia is longstanding and multifaceted, shaped by geographic, political, economic, social and technological factors. The level of organized and successful protests correlates with political systems, especially the accountability and policymaking powers of regional and local authorities. While a more open system in the Philippines produced local policy changes and enabled national coordination, the stratified Vietnamese political system has contributed to a more muted activism, yet online campaigns have partly filled the void. Protests in Indonesia have rarely produced policy changes in Jakarta, partly due to coordination difficulties and partly to weak enforcement of existing policies. Fears of losing agricultural, hunting and riverine livelihoods dominate in almost all anti-coal discourses across the region, but the threat coal poses to highly profitable industries such as tourism has also catalysed opposition. Climate-focused activism against coal is a facet of Thai and Philippine politics but is otherwise still nascent in most of Southeast Asia, although it is on the rise (Table 4.2). 
By 2020, coal mining and power generation had been growing in Southeast Asia for decades and were projected to rise to new heights of prominence in regional energy systems, weakening the energy security of all states in the region except Indonesia, jeopardizing the NDCs of the ASEAN states under the Paris Agreement and deepening existing domestic political fault lines. Coal utilization has well-known public health, agricultural, water security and economic consequences, many of which are magnified in Southeast Asia, with its high population density and limited wind and arable land. Paradoxically, the short-sighted focus on affordability imposes significant longer-term economic risks on these states as renewable energy prices fall, while ASEAN markets for such energy sources remain underutilized. Encouragingly, and likely partly spurred by sustained public resistance to coal and calls for climate action, EGAT in late 2019 announced that coal would account for only 12 per cent of power generation in 2037 in Thailand (Theepara and Praiwan, 2019).

Coal mining, no less hazardous in Southeast Asia than elsewhere, has triggered widespread locally organized protests in Indonesia, although not yet in Vietnam. While protestors have only achieved minor victories in some Indonesian cases, coordination amongst communities across the archipelago is increasing, and a nationally organized campaign in cooperation with international civil society might have a greater impact on Indonesia's coal-centric energy trajectory.

Coal plants and opposition to them are intertwined with existing socio-political fault lines: ethnic minority rights in Indonesia and Myanmar and regional political divides in Malaysia and Thailand. In Vietnam, the top-down one-party system blocks many protest avenues, which has triggered more creative and less overt forms of resistance against new coal-fired power plants. Opposition to coal across the region is heterogeneous, but trending towards greater national coordination and international cooperation amongst activist networks and even local governments. Local concerns continue to drive most protests, with the Philippines representing a more well-articulated pattern that links local and national environmental issues to climate change. International civil society organizations aiming to exert pressure on governments to reform their energy systems would do well to work more closely with activists on the ground in regions similar to Southeast Asia to shed an international spotlight on these issues, provide an international platform for local initiatives, make their case and form networks for collective action. This case shows how international actors as well as regional activists would stand to benefit substantially from closer cooperation, which has significant potential to pressure governments to abandon coal in Indonesia, Malaysia and Thailand. The international community has few direct tools or platforms through which pressure can be exerted on states to reconfigure their energy systems. Thus, the most viable option to effect change is through national and international coordination with global environmentalist NGOs, which can help harness, consolidate and empower the local efforts of Southeast Asian communities by linking local concerns with national policy trajectories to combat climate change.

\section{REFERENCES}

Amster, E. (2021). Public health impact of coal-fired power plants: a critical systematic review of the epidemiological literature. International Journal of Environmental Health Research 31, 559-80. 
Amster, E. and Lew Levy, C. (2019). Impact of coal-fired power plant emissions on children's health: a systematic review of the epidemiological literature. International Journal of Environmental Research and Public Health 16, 2008.

Anggoro, Y. and Simorangkir, D.A. (2019). Analysis of Indonesia mineral and coal mining safety management system policy using soft system methodology. Journal Manajemen Teknologi 18, 17-37.

AP (2015, 16 April). Vietnamese villagers block traffic to protest pollution. Accessed 14 August 2021 at https://apnews.com/article/973ff2038b314cdb94b9dbf49323e484.

Arsel, M., Akbulut, B. and Adaman, F. (2015). Environmentalism of the malcontent: anatomy of an anti-coal power plant struggle in Turkey. The Journal of Peasant Studies 42, 371-95.

ASEAN (2019). Joint Ministerial Statement of the 37th ASEAN Ministers on Energy Meeting, 4 September 2019. Bangkok, Thailand.

ASEAN Centre for Energy (ACE) (2017). ASEAN's Energy Equation. Jakarta: ACE/World Coal Association.

ASEAN Centre for Energy (ACE) (2019). Statistics. ASEAN Energy Database System. Accessed 14 August 2021 at https://aeds.aseanenergy.org/statistics/.

Ayling, J. and Gunningham, N. (2017). Non-state governance and climate policy: the fossil fuel divestment movement. Climate Policy 17, 131-49.

Ballard, C. (2001). Human Rights and the Mining Sector in Indonesia: A Baseline Study. Mining, Minerals, and Sustainable Development Report No. 182.

Bangkok Post (2018, 13 February). 33 plant protesters launch hunger strike.

Bangkok Post (2020, 8 March). How one woman is taking on Vietnam's 'big coal'.

Banktrack (2020). Vinh Tan III coal power plant Vietnam. Accessed 7 August 2021 at https://www .banktrack.org/project/vinh_tan_iii_thermal_coal_power_plant.

Bhuiyan, M.A.H., Parvez, L. and Islam, M.A. et al. (2010). Heavy metal pollution of coal mine-affected agricultural soils in the northern part of Bangladesh. Journal of Hazardous Materials 173, 384-92.

Blondeel, M., Van de Graaf, T. and Haesebrouck, T. (2020). Moving beyond coal: exploring and explaining the Powering Past Coal Alliance. Energy Research \& Social Science 59, Article 101304.

Brown, B. and Spiegel, S.J. (2017). Resisting coal: hydrocarbon politics and assemblages of protest in the UK and Indonesia. Geoforum 85, 101-11.

Buchanan, S., Burt, E. and Orris, P. (2014). Beyond black lung: scientific evidence of health effects from coal use in electricity generation. Journal of Public Health Policy 35, 266-77.

Bugnot, V. (2018, 13 July). How a small parish is leading the fight against coal in the Philippines. Eco-business.com. Accessed 7 August 2021 at https://www.eco-business.com/news/how-a-small -parish-is-leading-the-fight-against-coal-in-the-philippines/.

Burt, E., Orris, P. and Buchanan, S. (2013). Scientific evidence of health effects from coal use in energy generation. University of Illinois at Chicago School of Public Health.

Caldecott, B., Dericks, G. and Mitchell, J. (2015). Stranded Assets and Subcritical Coal: The Risk to Companies and Investors. Oxford: Smith School of Enterprise and the Environment, University of Oxford.

Carbon Tracker (2018a, 29 October). Economic and financial risks of coal power in Indonesia. Briefing.

Carbon Tracker (2018b, 29 October). Economic and financial risks of coal power in Vietnam. Briefing.

Carbon Tracker (2018c, 29 October). Economic and financial risks of coal power in the Philippines. Briefing.

Chen, J., Liu, G. and Kang, Y. et al. (2014). Coal utilization in China: environmental impacts and human health. Environmental Geochemistry and Health 36, 735-53.

Clark, R., Zucker, N. and Urpelainen, J. (2020). The future of coal-fired power generation in Southeast Asia. Renewable and Sustainable Energy Reviews 121, Article 109650.

Climate Analytics (2019). Decarbonising South and South East Asia: Shifting Energy Supply in South Asia and South East Asia to Non-fossil-fuel-based Energy Systems in Line with the Paris Agreement Long-term Temperature Goal and Achievement of Sustainable Development Goals. Berlin: Climate Analytics.

Cornot-Gandolphe, S. (2016). The role of coal in Southeast Asia's power sector and implications for global and regional coal trade. OIES Paper CL 4. Oxford Institute for Energy Studies, University of Oxford. 
Cornot-Gandolphe, S. (2017). Indonesia's electricity demand and the coal sector: export or meet domestic demand? OIES Paper CL 5. Oxford Institute for Energy Studies, University of Oxford.

Darmawan, L. (2019, 4 October). Hundreds protest pollution from coal-fired power plant in Java. Mongabay.com. Accessed 7 August 2021 at https://news.mongabay.com/2019/10/coal-power-plant -pollution-cilacap-indonesia/

Deboonme, A. (2012, 29 October). Hongsa project brings town power in more ways than one. Nationthailand.com. Accessed 7 August 2021 at https://www.nationthailand.com/Economy/ 30193162.

Dhillon, B.S. (2010). Global mine accidents. In B.S. Dhillon, Mine Safety: A Modern Approach, London: Springer, pp. 59-71.

Edenhofer, O., Steckel, J.C., Jakob, M. and Bertram, C. (2018). Reports of coal's terminal decline may be exaggerated. Environmental Research Letters 13, Article 024019.

Environmental Justice Atlas (2018). Hpa-An coal plant, Karen state, Myanmar. Accessed 14 August 2021 at https://ejatlas.org/conflict/hpa-an-coal-plant-myanmar.

Fatah, L. (2008). The impacts of coal mining on the economy and environment of South Kalimantan Province, Indonesia. ASEAN Economic Bulletin 25, 85-98.

Finkelman, R.B. and Tian, L. (2018). The health impacts of coal use in China. International Geology Review 60, 579-89.

Firdaus, F. (2018, 11 June). India eyes coal reserves in Indonesian Papua. Mongabay.com. Accessed 7 August 2021 at https://news.mongabay.com/2018/06/india-eyes-coal-reserves-in-indonesian-papua/.

Fulton, L., Mejia, A. and Arioli, M. et al. (2018). Climate change mitigation pathways for Southeast Asia: $\mathrm{CO}_{2}$ emissions reduction policies for the energy and transport sectors. Sustainability 9, 1160.

Funfgeld, A. (2018). Just energy? Social justice and the Indonesian coal sector. In T. Jafry (ed.), Routledge Handbook of Climate Justice. Abingdon: Routledge, pp. 222-6.

Gimon, E., O’Boyle, M., Clark, C. and McKee, S. (2019, 24 March). The coal cost crossover: economic viability of coal compared to new local wind and solar resources. Energyinnovation.org. Accessed 7 August 2021 at https://energyinnovation.org/publication/the-coal-cost-crossover/.

Global Energy Monitor (2020). Global Coal Plant Tracker. Accessed 29 April 2020 at https://endcoal .org/global-coal-plant-tracker/.

Green, F. (2018). The logic of fossil fuel bans. Nature Climate Change 8, 449-51.

Greenpeace (2018). Plans to expand a coal-fired power plant on Bali's north coast threaten one of the island's best-loved beaches and West Bali National Park. Accessed 14 August 2021 at https://www .greenpeace.org/southeastasia/story/1112/plans-to-expand-a-coal-fired-power-plant-on-balis-north -coast-threaten-one-of-the-islands-best-loved-beaches-and-west-bali-national-park/.

Hendryx, M. (2015). The public health impacts of surface coal mining. The Extractive Industries and Society 2, 820-26.

Hendryx, M., Zullig, K.J. and Luo, J. (2020). Impacts of coal use on health. Annual Review of Public Health 41, 397-415.

Henneman, L.R.F., Choirat, C. and Zigler, C.M. (2019). Accountability assessment of health improvements in the United States associated with reduced coal emissions between 2005 and 2012. Epidemiology 30, 477-85.

Higginbotham, N., Freeman, S., Connor, L. and Albrecht, G. (2010). Environmental injustice and air pollution in coal affected communities, Hunter Valley, Australia. Health \& Place 16, 259-66.

Hota, P. and Behera, B. (2015). Coal mining in Odisha: an analysis of impacts on agricultural production and human health. The Extractive Industries and Society 2, 683-93.

Huang, W., Ma, D. and Chen, W. (2017). Connecting water and energy: assessing the impacts of carbon and water constraints on China's power sector. Applied Energy 185, 1497-505.

International Energy Agency (IEA) (2019a). Coal Information 2019. Accessed 14 August 2021 at https:// www.iea.org/reports/coal-information-2019.

International Energy Agency (IEA) (2019b). Coal 2019: Analysis and Forecast to 2024. Paris: IEA.

International Energy Agency (IEA) (2019c). Southeast Asia Energy Outlook 2019. Paris: IEA.

International Energy Agency (IEA) (2020a). Myanmar Energy Master Plan. Accessed 14 August 2021 at https://www.iea.org/policies/6288-myanmar-energy-master-plan.

International Energy Agency (IEA) (2020b). IEA Singapore profile. Paris; IEA.

International Energy Agency (IEA) (2020c). IEA Brunei profile. Paris: IEA. 
International Renewable Energy Agency (IRENA), 2018. Renewable Energy Market Analysis Southeast Asia. Abu Dhabi: IRENA.

Jatam (2017). Thousands of anti-coal activists march in Jakarta, deliver complaints to anti-graft agency. Accessed 14 July 2021 at https://www.jatam.org/7222-2/.

Jewell, J., Vinichenko, V., Nacke, L. and Cherp, A. (2019). Prospects for powering past coal. Nature Climate Change 9, 592-7.

Johnsen, R., LaRiviere, J. and Wolff, H. (2019). Fracking, coal, and air quality. Journal of the Association of Environmental and Resource Economists 6, 1001-37.

Joibi, N. (2018). Talk of coal-mining in Sabah draws objections across the board. The Star, 23 September. Jong, H.N. (2019a, 21 August). Japan builds coal plants abroad that wouldn't be allowed at home. Mongabay.com. Accessed 7 August 2021 at https://news.mongabay.com/2019/08/japan-builds-coal -plants-abroad-that-wouldnt-be-allowed-at-home-report/.

Jong, H.N. (2019b, 29 September). Indonesia rushes to pass bill seen as pandering to mining companies. Mongabay.com. Accessed 7 August 2021 at https://news.mongabay.com/2019/09/indonesia-mining -coal-bill-law-controversial/.

Jong, H.N. (2020, 3 February). Borneo activists win a court battle to bar a coal miner from their land. Eco-business.com. Accessed 7 August 2021 at https://www.eco-business.com/news/borneo-activists -win-a-court-battle-to-bar-a-coal-miner-from-their-land/.

Kalkuhl, M., Steckel, J.C. and Montrone, L. et al. (2019). Successful coal phase-out requires new models of development. Nature Energy 4, 897-900.

Karensa, E. (2016, 13 June). Activists slam police's handling of Bengkulu anti-mining protest. Jakarta Globe. Accessed 7 August 2021 at https://jakartaglobe.id/news/activists-slam-polices-handling -bengkulu-anti-mining-protest/.

Karlsson-Vinkhuyzen, S.I., Groff, M. and Tamás, P.A. et al. (2018). Entry into force and then? The Paris Agreement and state accountability. Climate Policy 18, 593-9.

Kemp, L. (2018). A systems critique of the 2015 Paris Agreement on Climate. In M. Hossain, R. Hales and T. Sarker (eds), Pathways to a Sustainable Economy. Cham, Switzerland: Springer, pp. 25-41.

Kerimray, A., Rojas-Solórzano, L. and Amouei Torkmahalleh, M. et al. (2017). Coal use for residential heating: patterns, health implications and lessons learned. Energy for Sustainable Development 40, 19-30.

Koplitz, S.N., Mickley, L.J. and Marlier, M.E. et al. (2016). Public health impacts of the severe haze in Equatorial Asia in September-October 2015: demonstration of a new framework for informing fire management strategies to reduce downwind smoke exposure. Environmental Research Letters 11, Article 094023.

Kravchenko, J. and Lyerly, H.K. (2018). The impact of coal-powered electrical plants and coal ash impoundments on the health of residential communities. North Carolina Medical Journal 79, 289-300.

Lam, V. (2018, 27 June). Vietnam: a month of mass protests. Lowyinstitute.org. Accessed 7 August 2021 at https://www.lowyinstitute.org/the-interpreter/vietnam-month-mass-protests.

Le, Q. (2019, 7 March). Vietnamese provinces say 'no' to coal plants - government and industry still want more. Mekongeye.com. Accessed 7 August 2021 at https://www.mekongeye.com/?p=14003\& preview $=$ true.

Mekong Eye (2016, 3 April). Vietnamese campaign warns of nightmarish coal future. Accessed 7 August 2021 at https://www.mekongeye.com/2016/04/03/new-vietnamese-campaign-warns-of-a -nightmarish-coal-future/.

Ming, C.R., Ban Yu-Lin, A. and Abdul Hamid, M.F. et al. (2018). Annual Southeast Asia haze increases respiratory admissions: a 2-year large single institution experience. Respirology 23, 914-20.

Mon, S.L. (2019, 8 July). Villagers hold prayer protest against coal mine. The Myanmar Times. Accessed 7 August 2021 at https://www.mmtimes.com/news/villagers-hold-prayer-protest-against-coal-mine .html.

Munawer, M.E. (2018). Human health and environmental impacts of coal combustion and post-combustion wastes. Journal of Sustainable Mining 17, 87-96.

The Nation Thailand (2018a, 13 December). Thailand steps away from coal. Nationthailand.com. Accessed 7 August 2021 at https://www.nationthailand.com/perspective/30360369. 
The Nation Thailand (2018b, 27 January). Opponents to boycott new Krabi Power Plant. Nationthailand. com. Accessed 7 August 2021 at https://www.nationthailand.com/in-focus/30337304.

Ocharoenchai, N. (2019, 25 November). Beyond strikes: for these youths, climate activism starts at home. Mongabay.com. Accessed 7 August 2021 at https://news.mongabay.com/2019/11/beyond -strikes-for-these-youths-climate-activism-starts-at-home/.

Overland, I. (2018). Introduction: civil society, public debate and natural resource management. In I. Overland (ed.), Public Brainpower: Civil Society and Natural Resource Management. Cham, Switzerland: Springer, pp. 1-22.

Overland, I., Azlan, L. and Pich C. et al. (2017). Impact of climate change on ASEAN international affairs: risk and opportunity multiplier. Norwegian Institute of International Affairs.

Overland, I., Sagbakken, H.F. and Chan, H.-Y. et al. (2021). 'The ASEAN climate and energy paradox', Energy and Climate Change 2, Article 100019.

Paiwan, Y. (2019, 13 July). Egat begins public hearings for Mae Moh coal plant units. Bangkok Post. Accessed 7 August 2021 at https://www.bangkokpost.com/business/1711788/egat-begins-public -hearings-for-mae-moh-coal-plant-units.

Palatino, M. (2019, 25 September). A snapshot of climate strikes across Southeast Asia. Globalvoices. org. Accessed 7 August 2021 at https://globalvoices.org/2019/09/25/a-snapshot-of-climate-strikes -across-southeast-asia/.

Partlow, M. (2019, 12 March). NegOr marks first Renewable Energy Day. Pna.gov. Accessed 7 August 2021 at https://www.pna.gov.ph/articles/1063805.

Philippine Power Statistic (2018). Gross power generation by plant type. Department of Energy, Republic of the Philippines.

Prakash, A. (2018). Boiling point. Finance \& Development 55(3), 22-6.

Qadrdan, M., Byers, E. and Chaudry, M. et al. (2019). Electricity systems capacity expansion under cooling water availability constraints. IET Energy Systems Integration 1, 23-33.

Quek, A., Ee, A., Ng, A. and Wah, T.Y. (2018). Challenges in environmental sustainability of renewable energy options in Singapore. Energy Policy 122, 388-94.

Rauner, S., Bauer, N. and Dirnaichner, A. et al. (2020). Coal-exit health and environmental damage reductions outweigh economic impacts. Nature Climate Change 10, 308-12.

Richardson, B.J. (2017). Divesting from climate change: the road to influence. Law \& Policy 39, 325-48.

Runivarajom, P. (2018, 12 February). Anti-coal protestors start hunger strike, demand end to two projects. Nationthailand.com. Accessed 7 August 2021 at https://www.nationthailand.com/in-focus/ 30338680 .

San Jose, C. (2019, 8 March). Negros Occidental bans coal-fired power plants in favor of renewable energy sources. Nolisoli.ph. Accessed 7 August 2021 at https://nolisoli.ph/58582/negros-occidental -no-coal-power-plants-csanjose-20190308/.

Shani, N. (2019, 20 September). Can Indonesia relocate its capital without derailing its Paris Agreement targets? ASEAN Centre for Energy. Accessed 10 October 2019 at https://www.aseanenergy.org/blog/ can-indonesia-relocate-its-capital-without-derailing-its-paris-agreement-targets.

Shearer, C., Brown, M. and Buckley, T. (2019). China at a Crossroads: Continued Support for Coal Power Erodes Country's Climate Leadership. Institute for Energy Economics and Financial Analysis.

Shi, X. (2016). The future of ASEAN energy mix: a SWOT analysis. Renewable and Sustainable Energy Reviews 53, 672-80.

Silva, L.F.O. and da Boit, K.M. (2011). Nanominerals and nanoparticles in feed coal and bottom ash: implications for human health effects. Environmental Monitoring and Assessment 174, 187-97.

Sternagel, F. (2018, 19 October). Coal power plants in Myanmar: recurring plans, recurring protests. Heinrich Boll Stiftung, Yangon.

Strasert, B., Teh, S.C. and Cohan, D.S. (2019). Air quality and health benefits from potential coal power plant closures in Texas. Journal of the Air \& Waste Management Association 69, 333-50.

Tacconi, L. (2016). Preventing fires and haze in Southeast Asia. Nature Climate Change 6, 640-43.

Taghizadeh-Hesary, F. and Taghizadeh-Hesary, F. (2020). The impacts of air pollution on health and economy in Southeast Asia. Energies 13, 1812.

Thant, H. (2019, 20 August). Myanmar continues coal-plant plans. The Myanmar Times. Accessed 7 August 2021 at https://www.mmtimes.com/news/myanmar-continues-coal-plant-plans.html. 
Theepara, C. and Praiwan, Y. (2019, 25 January). National power plan expands private output. Bangkok Post. Accessed 7 August 2021 at https://www.bangkokpost.com/business/1617382/national-power -plan-expands-private-output.

Thomas, J. (2019, 29 October). Duterte's push for 'clean coal'. The ASEAN Post. Accessed 7 August 2021 at https://theaseanpost.com/article/dutertes-push-clean-coal.

Tondo, F.H. and Siburian, R. (2019). Techniques of mining and land grabbing: destruction of agricultural activities in Kerta Buana Village, East Kalimantan - Indonesia. Asian Journal of Agricultural Extension, Economics \& Sociology 35, 1-14.

Toumbourou, T., Muhdar, M., Werner, T. and Bebbington, A. (2020). Political ecologies of the post-mining landscape: activism, resistance, and legal struggles over Kalimantan's coal mines. Energy Research \& Social Science 65, Article 101476.

Tran, N.T.D., Pham Le, P.A. and Le Thi, T.L. (2019, 2 June). Coal-based power plants: Viet Nam's unsolved problem. Friedrich Ebert Stiftung.

Trinks, A., Scholtens, B., Mulder, M. and Dam, L. (2018). Fossil fuel divestment and portfolio performance. Ecological Economics 146, 740-48.

United Nations Framework Convention on Climate Change (UNFCCC) (2015). Paris Agreement. Accessed 19 July 2021 at https://unfccc.int/files/meetings/paris_nov_2015/application/pdf/paris agreement english .pdf.

Vakulchuk, R., Hlaing, K.K. and Naing, E.Z. et al. (2017). Myanmar's attractiveness for investment in the energy sector: a comparative international perspective. Accessed 14 August 2021 at https://papers .ssrn.com/sol3/papers.cfm?abstract_id $=3023133$.

Vanda, K. (2019, 12 September). Electricity capacity to expand with Laos coal deal. Vodenglish.news. Accessed 7 August 2021 at https://vodenglish.news/electricity-capacity-to-expand-with-laos-coal -deal/.

Wang, Y., Byers, E. and Parkinson, S. et al. (2019). Vulnerability of existing and planned coal-fired power plants in developing Asia to changes in climate and water resources. Energy \& Environmental Science 12, 3164-81.

Watcharejyothin, M. and Shrestha, R.M. (2009). Effects of cross-border power trade between Laos and Thailand: energy security and environmental implications. Energy Policy 37, 1782-92.

Win, A.N. and Win, S.P. (2016, 15 March). Local resistance fails to halt Myeik coal-fired power plant. The Myanmar Times. Accessed 7 August 2021 at https://www.mmtimes.com/business/19465-local -resistance-fails-to-halt-myeik-coal-fired-power-plant.html.

World Coal Association (WCA) (2019, 12 November). Rising energy demand in Southeast Asia to be met and supported by coal. WCA.

Xiao, X., Zhang, J. and Wang, H. et al. (2020). Distribution and health risk assessment of potentially toxic elements in soils around coal industrial areas: a global meta-analysis. Science of the Total Environment 713, Article 135292.

Yu, X., He, D. and Phousavanh, P. (2019). Case study: experience sharing in Laos. In X. Yu, D. He and P. Phousavanh (eds), Balancing River Health and Hydropower Requirements in the Lancang River Basin. Singapore: Springer, pp. 259-83.

Yuan, J., Na, C. and Lei, Q. et al. (2018). Coal use for power generation in China. Resources, Conservation and Recycling 129, 443-53.

Zhang, X., Liu, J. and Tang, Y. et al. (2017). China's coal-fired power plants impose pressure on water resources. Journal of Cleaner Production 161, 1171-9.

Zhao, S. and Alexandroff, A. (2019). Current and future struggles to eliminate coal. Energy Policy 129, 511-20. 